\title{
Could This Be the African Century?
}

\author{
Carlos Lopes
}

\begin{abstract}
Demography will shape Africa's future. Africa's current population is 1.3 billion. Some forecast that, it will double by 2050 . This essay contends that narratives about Africa tend to be negative. If Africa is home to 2.6 billion people, or a quarter of the world's population, Africa will play a decisive role in shaping the future of the world. A number of socio-economic indicators support an African Century narrative, which would result in a shift from policies driven by perception to those driven by reality. The youth bulge in Africa, if managed properly is, for instance, not just a fuel for African economies, but also for the rest of the world, especially Europe. Chinese investors in Africa adjust to the local context extremely quickly, and are not perceived as expatriates having living standards way above the rest. They instill an entrepreneurial "can do" attitude against adversity. Chinese perception of risk is also very different from traditional western investors. These characteristics make China a good partner for the industrialization policies being pursued by African countries.
\end{abstract}

Keywords Demography will shape Africa's future $\cdot$ Africa's current population is 1.3 billion $\cdot$ Narratives about Africa tend to be negative $\cdot$ Africa will play a decisive role in shaping the future of the world $\cdot$ African Century narrative $\cdot$ The youth bulge in Africa $\cdot$ Chinese investors in Africa $\cdot$ Chinese perception of risk is also very different

Narratives about Africa tend to be negative. Embedded in historical simplifications and dismissiveness the current changes being observed on the mainstream views about the continent have a lot to do with a stronger agency and significant achievements. While the 'Africa Rising' storyline tends to on about new business opportunities, more voices admit the possibility of an African century.

The adoption of the UN's Millennium Declaration-and its companion Millennium Development Goals_-inaugurated a new era. Prescriptive structural adjustment policies were replaced by goals, meaning different ways of attaining objectives or, in economic jargon, policy space. Around the year 2000, Africa started to demonstrate a

C. Lopes $(\bowtie)$

Mandela School of Public Governance, University of Cape Town, Cape Town, South Africa

(C) The Author(s) 2021

H. Wang and A. Michie (eds.), Consensus or Conflict?, China and Globalization,

https://doi.org/10.1007/978-981-16-5391-9_29 
different pattern of economic behavior. For the last decade, African countries systematically dominated the list of the top-10 fastest-growing economies in the world. In 2019, the IMF forecasts indicated that six of the ten fastest-growing economies in the world would be in Africa ${ }^{1}$ (Ethiopia, Ghana, Ivory Coast, Rwanda, Senegal, and South Sudan). Economic growth resulted in Africa doubling its Gross Domestic Product (GDP) within a period of 12 years. Even though growth has slowed down due to a challenging global context, the continent's performance is second only to Southeast Asia.

A number of socio-economic indicators have also fueled the African Century narrative. By 2010, the middle class had risen to $34 \%$ of Africa's population, ${ }^{2}$ up from $27 \%$ in 2000. Such growth — of 3.1\% — in the middle class between 1980 and 2010 is higher than the $2.6 \%$ growth rate of the total population. The middle class, although arguably still vulnerable, is viewed as fuel for the economies of the continent. In 2017, household spending reached USD 1.6 trillion $^{3}$ after passing the USD 1 trillion mark in 2010. This is on par with large economies such as China. By 2025, household spending is projected to reach USD 2.5 trillion according to estimates by McKinsey Global Institute and the Brookings Institute. ${ }^{4}$

However, growth experience alone is indeed not sufficient to claim the twentyfirst century. Africa grew quickly, but transformed slowly, putting in jeopardy many of the gains so far registered. The forecasted 4\% GDP growth for $2019^{5}$ remains far short of the $7 \%$ minimum percentage required to double the average income in a decade. This is partly due to the fact that too many African economies still depend on the production and export of primary commodities.

\section{Growth with Transformation}

The good news is that attractive solutions are known. Translating growth into meaningful developments for African countries will require an aggressive industrialization agenda. Africa is not a desert when it comes to manufacturing and industrialization. Attempts to industrialize in the 1960s and 1970s by adopting an import-substitution model of industrialization had mixed results. While this led to some remarkable progress, it quickly showed the limits of state-led production rather than state-led facilitation. Manufacturing value addition as a percentage of the GDP has been declining since the introduction of liberal policies promoted by structural adjustment programs. However, since the overall economy has grown considerably, the

\footnotetext{
${ }^{1}$ https://www.bloomberg.com/news/articles/2019-04-10/ghana-is-the-star-in-imf-s-2019-eco nomic-growth-forecast-chart.

${ }^{2}$ https://www.afdb.org/fileadmin/uploads/afdb/Documents/Publications/TheMiddleofthePyramid_ TheMiddleofthePyramid.pdf.

${ }^{3}$ https://qz.com/africa/1486764/how-big-is-africas-middle-class/.

${ }^{4}$ https://www.brookings.edu/research/africas-consumer-market-potential/.

${ }^{5}$ https://www.afdb.org/en/knowledge/publications/african-economic-outlook/.
} 
value addition percentage hides the fact that the real production of manufactured goods has gone up significantly too. Yet the concentration of such industrial bases in a few countries and sectors demonstrates that an overall structural transformation is still missing in action.

The quest for industrialization is not over in Africa. Domestic manufacturing in Africa doubled between 2000 and 2010 according to the African Development Bank and continues to increase thanks to investments in the retail clothing manufacturing sector by the likes of H\&M, Primark, and Levi's; car manufacturing by the likes of Volkswagen, Mercedes, Renault, Peugeot, among others; Seemahale Telecoms in the mobile phone segment; and by the aviation and automobile parts sector in countries like Morocco and Tunisia. Local investors have also boosted the manufacturing sector on the continent notably in electronics (mobile phone, computers) by manufacturers such as Algeria's Condor Electronics and the Mara Group in Rwanda; the pharmaceuticals sector-a sector valued at USD 65 billion $^{6}$ by 2020 , therefore, matching India's pharmaceutical sector-with companies such as Algeria's Saidal, Biofarm, and Merinal Laboratories, among others, which produce $47 \%$ of locally purchased medical products, South Africa's Aspen and Adcock Ingram, Tunisia's laboratories which managed to increase local production from 14\% in 1990 to $45 \%$ in 2010. And the list goes on to include companies elsewhere on the continent in countries including Angola, Cameroon, Egypt, Ethiopia, Ghana, Kenya, Lesotho, Mauritius, Morocco, Nigeria, Tanzania, and Uganda.

Agro-processing, delocalization of low value-added manufacturing in Southeast Asia due to labor costs rise there, as well as commodity-based industrialization hold the key for a more radical transformation.

For African countries endowed with natural resources, focusing energies on exploiting and transforming the wealth of the country can be far more promising than trying to diversify away from commodities. Despite criticism of this model of industrialization, largely due to the argument that it is unlikely to promote linkages, experiences from other resource-rich countries such as Argentina, Malaysia, Thailand, Australia, Norway, and Scotland show that such model can deliver economic growth. Examples from within Africa itself demonstrate that such a model can be promising in terms of developing elements of an ecosystem that promotes innovation, value addition as well as quality employment.

Agriculture represents also an important vehicle for resource-based industrialization. Agriculture accounts for almost $65 \%$ of Africa's employment and $75 \%$ of its domestic trade. In addition, the agri-food sector has already made some strides on the continent and has significant potential with estimates putting its value at USD 1 trillion by $2030 .^{7}$ The sector can generate significant productivity gains in rural areas with vibrant hubs of agri-business and linkages across value chains.

\footnotetext{
${ }^{6}$ https://www.mckinsey.com/industries/pharmaceuticals-and-medical-products/our-insights/afr ica-a-continent-of-opportunity-for-pharma-and-patients.

${ }^{7} \mathrm{https}$ ://agra.org/agribusinesses-and-african-smallholders-seize-1-trillion-food-market-as-mealsreplace-minerals-to-restart-african-economic-growth-new-report/.
} 
To fully reach this potential, it will be important to improve land productivity. Africa's land productivity is stuck at 1.5 tons per hectare, while in countries like India, land productivity has grown from 0.95 tons/ha to 2.53 tons/ha over the past 50 years. This is despite the fact that agricultural land in Africa is three to six times higher than in countries like China and India, both of which have successfully managed to secure food for their "bottom billion" despite having much lower available agricultural land per capita, while Africa continues to be the world's most food-insecure region.

Small-scale farmers will be important players in this transformation. But they need support and innovation. Most African farmers have not benefited from initiatives and programs aimed at improving farming techniques, farm equipment, seeds, fertilizers, post-harvest technology, and agricultural financing. But some interventions, although still too timid and sparse, stand out as possible routes to enable the integration of small-scale farmers in the quest for higher productivity in African countries. For example, the interventions of the government of Ghana to introduce mechanized farming systems and make block farming a reality for small-scale farmers have successfully turned the country into an established food basket. Egypt's rice yield today stands at nine metric tons per hectare, making it the best rice output in the world. Water harvesting in Tanzania has been successfully scaled up in the lowlands, where seasonal rainfall can amount to as much as 600-900 $\mathrm{mm}$, improving the Majaluba rain-fed rice farms. With the help of low-cost individual pump schemes, Nigerian farmers have turned to small-scale irrigation by using shallow groundwater recharged by rivers and lifting it with shadouf and calabash in the dry season to grow vegetables for city dwellers.

Transforming African economies through resource-based industrialization will not be easy. It will require innovation, skills, robust knowledge base of the industry structure and global value chains. It would also require African countries to be particularly attuned to the global trading landscape, including barriers and preferential policies. However, boosting intra-Africa trade remains imperative for creating the markets that are needed for successful industrialization.

The entry into force of the African Continental Free Trade Area (AfCFTA) in May 2019 is potentially an important game changer. From this year, Africa has the largest free trade area in the world by size-with its 1.2 billion person consumer market. The combined consumer and business spending is expected to hit USD 6.7 trillion within the next 10 years. ${ }^{8}$ The Economic Commission for Africa expects AfCFTA intra-African trade (currently standing at $20 \%$ ) to expand by $52 \%$ by cutting tariffs on $90 \%$ of goods traded across the continent to zero.

Admittedly, the transition will not be without consequences-at least for some time. Experiences in countries that have undergone such transformations show that there is a strong historical pattern of worsening income distribution between rural and urban economies during the initial stages of structural transformation. As the urban population in Africa is projected to double in size to eventually reach 2.3 billion people over the next 40 years, it is likely that such a pattern would be further accentuated. However, we also know from historical data that absolute poverty does

\footnotetext{
${ }^{8}$ https://www.weforum.org/agenda/2018/03/capturing-africa-s-high-returns.
} 
not necessarily worsen during such episodes, therefore, reducing the risk that the strides made in fighting extreme poverty in Africa over the last two decades are unlikely to be reversed.

\section{Changing Perceptions}

Transformation requires capital, which will need to be generated in international markets, through foreign direct investment. Yet, Africa remains marginal as a destination for foreign investors. Such reluctance is often justified by exaggerated risk perceptions, often dominated by security and governance concerns.

The turn of the century witnessed some progress in Africa in the area of political governance, peace, and security. Despite pockets of violence, there is consensus that the nature of politics in Africa is changing. The appetite of the continent's population for political participation has increased as demonstrated by the increase in political contestation on the continent from the events we have seen this year in Sudan and Algeria to the events of the Arab Spring, Burkina Faso, and many other countries on the continent. Youth, particularly those residing in urban areas operate in political spaces in similar ways to their counterparts ${ }^{9}$ elsewhere in the world. In addition, conflicts have receded across the continent largely driven by improvements in political governance across the continent. Although recent years saw increases in violent incidents, incidents of violent death as a result of conflict remains significantly lower than what the continent witnessed in the early 1990s. Furthermore, the increase is largely attributed to global dynamics and especially the rise and expansion of the Islamic State in the Sahel and West Africa. ${ }^{10}$

Yet, despite the decline in the number of conflicts in Africa, the continent continues to be viewed as conflict-ridden. Unlike Asia, conflicts in Africa are not seen as isolated. The conflicts in Mindanao do not shape the image of the Philippines. The Sabah insurgency does not shape the image of emerging Malaysia. There were about 29 piracy attacks in 2009 off the coast of Somalia as compared to 150 attacks in the strait of Malacca, between Malaysia and Singapore, in 2005. The Naxalite insurgency and the issue of Kashmir do not shape investors' image of a rising India. And South Korea remains unaffected by its proximity to its belligerent sister state to the north. Indeed, despite the widespread nature of conflict in Asia, the region is branded as dynamic rather than unstable.

Perception shapes engagement (public and private) in different ways. Structural transformation requires a different type of engagement that taps into the potential of the continent rather than seeing it as a high-risk region or at best a charity basket case. Development aid, albeit still important in specific cases, cannot single-handedly

\footnotetext{
${ }^{9}$ https://afrobarometer.org/sites/default/files/publications/Working\%20paper/AfropaperNo136. pdf.

${ }^{10} \mathrm{https}: / /$ reliefweb.int/sites/reliefweb.int/files/resources/Conflict $\% 20$ Trends $\% 20$ in $\% 20$ Africa $\%$ 2C\%201946\%E2\%80\%932017\%2C\%20Conflict\%20Trends\%20Report.pdf.
} 
transform African economies at a time when the demography of the continent requires bold action. Africa's youth can be an asset, but that requires a different form of engagement. In West Africa for instance, the sub-regional grouping ECOWAS estimates that more than 2 million youth who enter the market every year do not have access to jobs. ${ }^{11}$ The African Development Bank estimates that 10 to 12 million youth enter the workforce ${ }^{12}$ each year, but that only 3.1 million are absorbed. Support to agriculture, which would play a key role in transforming African economies and integrate a large portion of the labor force, did not benefit from strategic investments. Numbers do not mean impact. For example, in 2002, Africa received almost double the amount of ODA for agriculture (USD 713.6 million) that was given to the countries of East and Southern Asia (USD 479.8 million). However, this did not translate into per-dollar greater returns largely because it was treated in isolation of the infrastructure and technological innovations that would stretch impact.

Tapping into the potential offered by Africa's growing population and consumer market means engaging through investments in key enabling sectors. Despite the perceived challenges, China, besides being Africa's main trading partner, has become Africa's main infrastructure financier and builder. Concerns about the indebtedness of African countries to China have been raised, but it is important to remember that, despite the recent surge in debt, the debt to GDP ratio in Africa has not dramatically increased and remains the lowest in the world after that of the rich Gulf States region, if reserves are taken into consideration, is sometimes negative.

The COVID-19 pandemic was yet another crucial moment in defining Africa's relationship with the world. Global economic governance was seriously disrupted and the African position suffered consequently. Debates about the socio-economic impact of the pandemic outpaced the preoccupations with the sanitary dimensions, given the fact that the continent registered lower levels of infections and lethality. The lessons learned from growing protectionism, disruption of supply chains, the drastic drop in demand, and paralysis in the informal sector all pointed to the need to accelerate Africa's industrialization and regional integration. Trade emerged as a key element for the continent to get its act together and better negotiate. Without a common position in major debates, Africa appears weakened in light of exogenous shocks as amply verified during the pandemic.

\section{Benefiting Africa and Beyond}

Reaching Africa's full potential requires the political courage to ask all international partners to look beyond. For example, African countries fought hard to obtain preferential rules of origin for the least developed countries at the nineteenth Ministerial Conference of the WTO in 2013. Yet, they have not called for the implementation of

\footnotetext{
${ }^{11} \mathrm{https}: / / \mathrm{www}$. youtube.com/watch?v=D3ZmaGLNuaU\&app=desktop.

${ }^{12} \mathrm{https}: / /$ www.afdb.org/fileadmin/uploads/afdb/Images/high_5s/Job_youth_Africa_Job_youth_ Africa.pdf.
} 
those preferential criteria in their bilateral negotiations with the EU under Economic Partnership Agreements (EPAs) or requested the same under the African Growth and Opportunity Act (AGOA) with the United States.

It is time for engagement with international partners to shift from policies and frameworks driven by perception to those driven by reality and a common vision for the future. The youth boom in Africa, if managed properly, will not only drive African economies, those in the rest of the world, especially Europe. A recent study by the Bertelsmann Foundation, for instance, shows that intra-EU migration will no longer be able to satisfy the needs of Germany's economy, requiring it to rely on 146,000 workers per year from non-EU countries. ${ }^{13}$ Yet, the migration of African youth is currently viewed largely as a threat rather than an opportunity, with the EU caving in to pressure from its right-wing politicians. The reality, however, shows that Africans are far from making up the majority of non-EU migrants entering Europe. The rate of Chinese migration to Europe is double that of Africans and the proportion of African nationals in Europe is similar to numbers in the 1970s. Those wishing to migrate also tend to be more educated. ${ }^{14}$ Concerns about refugees are also unjustified as Africa continues to bear the brunt of wars with $80 \%$ of refugees remaining in Africa.

A future-focused engagement also requires international partners to move beyond classical development aid models. Limiting Europe's engagement with Africa to mechanisms of aid disbursements that have been in place since the 1970s does not bode well for the future. Where the EU sought to be innovative, it developed initiatives without consulting African countries, isolated from the plethora of initiatives and mechanisms in place in Africa as well as Europe. These fragmented approaches to dealing with Africa do not only risk inefficient use of the resources to the detriment of both Europe and Africa, but further jeopardizes the close relationship between the two continents by further undermining Africa's own efforts and agency in its development agenda.

\section{The Role of China in the Promotion of African Agency}

China's relationship with Africa is changing. From what was once a narrative built on the sale of primary commodities to fuel China's booming economic growth, it is increasingly being defined by an emerging, confident Africa with its own socio-economic and political priorities. Many African countries are now demanding tangible and credible benefits beyond rent seeking based on natural resource exports. In short, China's relationship with Africa has transformed into one defined by dynamism and African agency, lessening the hold the former previously had.

\footnotetext{
${ }^{13} \mathrm{https} / / / \mathrm{www} . \mathrm{dw} . c o m /$ en/study-germany-needs-260000-immigrants-a-year-to-meet-labor-dem and/a-47470731.

${ }^{14} \mathrm{https} / / /$ www.afrobarometer.org/blogs/african-migration-whos-thinking-going-where.
} 
China's Africa Policy is best analyzed from its unique political and economic perspectives. Although China reaps considerable economic gains from Africa, it would be simplistic to regard those benefits as the sole driver of China's policy.

Media outlets and Western scholars often suggest that China's relationship with Africa is built on its dependency on natural and energy resources, as well as markets, and investment opportunities for its booming industries and job-seeking workers. Indeed, China has often been criticized for taking advantage of Africa's vulnerability. This perception, however, fails to take into account that China is no different from any global player: it defends its interests; it does it in its own terms; and cannot avoid tensions between those interests and values. It also shows a condescending attitude toward Africans, assuming that they need someone to help them coordinate relationships according to a moral compass defined by well-meaning outsiders.

China can no longer be expected to subordinate its commercial and strategic interests to others. Most African countries that have benefited from China's increasing trade, investment, and debt relief, are not endowed with mineral wealth, offering fewer investment opportunities for Chinese enterprises. They are interesting for China for other reasons.

Even though Africa remains a relatively marginal player when it comes to China's overall trade with the rest of the world, its trading relationship with China has important implications for both. Africa serves as a low-value consumer market for Chinese goods, particularly for loss-making state-owned enterprises, which have set up shops across the continent. Increased labor costs in China have created new opportunities for the delocalization of low-margin Pearl River manufacturing sectors to other parts of the world. Chinese entrepreneurs have knowledge of supply chains, contacts with major world retailers, possess the capital and investment appetite to deal with difficult environments, and can now replicate their processes in hubs in Africa at will.

Chinese investors are good politicians that adjust to the local context extremely quickly and are not perceived as expatriates demanding living standards far above local levels. They tend to be hard workers and instill the market with an entrepreneurial "can do" attitude. Perhaps their biggest difference is their perception of risk, which is very different from traditional western investors. These characteristics make China a good partner for the industrialization policies being pursued by African countries.

Ultimately, it is the responsibility of African leaders to devise a strategy for their relations with China; not for China to be responsible for a mutually beneficial relationship. It is important to retain a more nuanced view of the relationship, which is more of a two-way road. The interest and motivation of Africans to expand their presence in China is also real, but less reported.

Carlos Lopes is a Professor at Nelson Mandela School of Public Governance, University of Cape Town; Visiting Professor at Sciences Po, Paris, and Associate Fellow at Chatham House, London. He was a 2017 Fellow at Oxford Martin School, University of Oxford. Previously he Chaired the Lisbon University Institute Board and occupied prominent positions such as UN Assistant 
Secretary-General and Political Director for Secretary-General Kofi Annan and Executive Secretary of the UN Economic Commission for Africa. He is currently the African Union High Representative for Partnerships with Europe and a member of the African Union Reform Team. Widely published, he has received many awards and honorary doctorates and has integrated 20 times the lists of most influential Africans of the main pan-Africa media.

Open Access This chapter is licensed under the terms of the Creative Commons AttributionNonCommercial-NoDerivatives 4.0 International License (http://creativecommons.org/licenses/bync-nd/4.0/), which permits any noncommercial use, sharing, distribution and reproduction in any medium or format, as long as you give appropriate credit to the original author(s) and the source, provide a link to the Creative Commons license and indicate if you modified the licensed material. You do not have permission under this license to share adapted material derived from this chapter or parts of it.

The images or other third party material in this chapter are included in the chapter's Creative Commons license, unless indicated otherwise in a credit line to the material. If material is not included in the chapter's Creative Commons license and your intended use is not permitted by statutory regulation or exceeds the permitted use, you will need to obtain permission directly from the copyright holder.

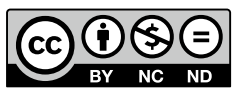

